\title{
Put Your Money Where Your Mouth Is: Early Modern Economics, Comedy, and Point of View in Lazarillo de Tormes
}

Este trabajo propone que el análisis detenido del uso de una determinada terminología económica en dos episodios del primer tratado de Lazarillo de Tormes, el de las medias blancas y el de la longaniza y el nabo, indica que el texto es tanto una obra de entretenimiento cómica como una sátira de los mercaderes-banqueros que formaban parte de la burguesía ascendente de la Castilla de mediados del siglo XVI. Así, Lazarillo emplea el humor y la ironía para desarrollar, no una celebración de la incipiente burguesía castellana, sino una sátira de la clase financiera por su avaricia e hipocresía.

Palabras clave: Lazarillo de Tormes, economía, cambiadores, bufones, sátira

This essay contends that careful analysis of the use of specific economic terminology in two episodes of the first tractado of Lazarillo de Tormes, that of the medias blancas and that of the sausage and the turnip, reveals that the text is both a work of comic entertainment and a satire of the merchantbankers who were part of the ascendant bourgeois class in mid-sixteenthcentury Castile. Thus, Lazarillo employs humour and irony to develop, not a celebration of the incipient Castilian bourgeoisie, but, rather, a satire of the financial class for their greed and hypocrisy.

Keywords: Lazarillo de Tormes, economics, moneychangers, buffoons, satire

A growing body of scholarly literature reads Lazarillo de Tormes in the context of profound changes in the socio-economic structure of midsixteenth-century Castile, as the older feudal-agrarian system gave way to a new model of commerce and finance. In this view, Lazarillo presents a proto-bourgeois ethic by means of which the narrator-protagonist achieves economic independence and personal autonomy outside the strictures of the hierarchical society, while simultaneously appropriating and subverting the authoritarian discourse of the dominant social classes as part of a deliberate strategy of personal vindication and self-defence. ${ }^{I}$ 
This reading is consonant with the predominant critical approach to Lazarillo, established in influential studies by Claudio Guillén, Fernando Lázaro Carreter, and Francisco Rico (Novela picaresca), which treats the book as the precursor to the modern novel by virtue of the cohesive psychological profile that develops organically through the presentation of the narrator's monadic point of view. ${ }^{2}$ Lázaro is fully aware of being a cuckold, but he overlooks the offense to his honra in furtherance of his material provecho, thus silently indicting contemporary society for its hypocrisy and exploitation of the poor.

Anthony Close cuts against this critical grain by locating Lazarillo de Tormes in the realm of the comic, which he finds incompatible with the psychological realism that critics such as Rico attribute to Lázaro: "The essential risibility of Lazarillo, as Rico himself perceived ... puts in question the sophisticated purposes that he attributes to it, whose basis is the psychological coherence of Lázaro's relation to his own past and to the addressee of his story, that anonymous 'Vuestra Merced' (Sir)" (285). Close points out that the pícaro "was considered the lowest of the low, ragged and abject, fit only for menial occupations such as basket carrier, kitchen skivvy, beggar. In line with the traditional equation of low subject matter with plain style and comicality, it was taken for granted that such an individual could only be considered a figure of fun" (285). Drawing on the work of Maxime Chevalier, Close observes that contemporary readers reacted to Lazarillo as a series of independent episodes based on traditional pranks. This attitude, in turn, conditioned those readers' response to Lázaro's literary character, which was predicated on three traditional functions: I) a trickster who learns to survive and outwit his masters; 2) a raconteur who tells his story in an appropriately witty style; 3) a gullible dupe who is foolishly deceived by appearances from beginning (the stone bull) to end (his sham marriage to the archpriest's mistress). The third characteristic is obviously incommensurate with the first two, a fact that seems never to have bothered anyone and not even to have occurred to Lazarillo's first editors or the authors of its sequels (Close 286). 3 To be sure, the evident care that the anonymous author put into the text's structural symmetries appears to belie Close's beads-on-a-string metaphor (Guillén 264-65; Rico, Novela picaresca 26-37; Friedman 46). Such patterning is not exclusive to the modern novel, however, but is characteristic of traditional plot-driven narrative modes (Frye 47-50).4 As to Lazarillo's ostensible verisimilitude, Close points out that the principal critical assumption behind it, namely, Lázaro's cynicism in narrating his own cuckoldry, undermines the realism of his tale: 
Whoever, in that age, with all its prickly prejudices about honour, would have chosen to seek authorial fame and moral self-justification by pushing under society's nose the transparent evidence of his own marital horns? And furthermore, whoever would have done so with such flippant drollery and smirking innuendo as to incite, quite deliberately, the derision that these disclosures naturally prompt? Clearly, nobody would, other than in the extravagant world of comic fantasy, or, conceivably, in a pose jestingly adopted by a professional buffoon. (286-87)5

In fact, Francisco Márquez Villanueva and Victoriano Roncero López argue that Lazarillo, and Spanish picaresque fiction generally, evolved precisely from the highly developed tradition of buffoon literature in Castile, which crystalized into an epistolary and satiric genre in the first half of the sixteenth century (Márquez Villanueva 520-22; Roncero López 55-95). Within this tradition, the buffoon seeks to provoke laughter in the social superiors whom he addresses while simultaneously criticizing morally censurable aspects of his society. The key figure in the development of this satirical conception of humour in the early modern period is Erasmus, especially his Moriae Encomium, and his recuperation of Horace's dictum ridentem dicere verum: "Para el humanista de Róterdam, a través del humor, los locos y los bufones son los únicos autorizados en la corte para poder decir las verdades a los monarcas o a los nobles, sin recibir por ellos ningún castigo" (Roncero López 46). The buffoon's marginal social status potentiates this critical discourse: "Auto zaherirse, hacer gala de su propia indignidad, en suma, reírse de sí mismo, le concedía al autor la licencia para burlarse de los demás, para sacar al público sus vergüenzas" (Roncero López 70). Paradoxically, however, this criticism does not necessarily entail a desire on the part of the buffoon to subvert the established social order. On the contrary, he achieves a degree of individual agency precisely because of his ability to manipulate a rigidly hierarchical system (Roncero López 69).

Both Márquez Villanueva and Roncero López affirm that Lázaro's status as a degraded object of comic mockery subject to physical abuse and social deprecation, but who nonetheless functions as a satirical observer of contemporary society, is the legacy of buffoon literature. According to Márquez Villanueva, Lazarillo de Tormes constitutes "una epístola festiva, escrita por un paradigma de infamia para entretenimiento de cierto poderoso reconocido como 'Vuestra Merced.' Se continúa, pues, dentro de la bipolaridad habitual de la relación bufonesca" (520). Roncero López, in turn, asserts that Lazarillo simultaneously evinces "una clara finalidad de hacerle pasar un buen rato [al lector]," and participates in: 
la función que la tradición clásica, recogida por Erasmo, atribuía a los bufones de hacer reír y, al mismo tiempo, criticar todo aquello que consideraban digno de ser criticado ... No es, pues, incompatible la lectura humorística de la novela con una posible intencionalidad crítico moralizante que ha sido destacada por algunos críticos. $(66)^{6}$

In the analysis that follows, I propose to build on these important critical insights by applying them to a consideration of Lazarillo's economic content, which neither Márquez Villanueva nor Roncero López discuss.7 I contend that a careful analysis of the economic terminology that occurs in two episodes of the tractado primero indicates that Lazarillo de Tormes satirizes contemporary cambiadores, the newly ascendant class of merchant-bankers and financiers, for their avarice and hypocrisy. In other words, I read Lázaro's letter to Vuestra Merced as, in part, a satire of precisely the emergent bourgeoisie that most other critics who focus on similar aspects of the story suppose it celebrates. Treating Lázaro as a satirical narrator in the vein of the self-debasing but subversive buffoon authors studied by Márquez Villanueva and Roncero López (e.g. Francisco López de Villalobos and Francesillo de Zúñiga) allows us to reconcile the character's apparently comic ingeniousness in telling his tale - as sixteenth-century readers appear to have assumed and Close argues - with a morally censorious and psychologically complex perspective that modern readers overwhelmingly take for granted but that contemporary concepts of literary decorum rendered utterly incongruous in the mouth of a low-born, marginalized figure of ridicule. In this reading, Lázaro's assumption of a self-incriminating "pose jestingly adopted by a professional buffoon," as Close puts it, is indeed a source of merriment for his diegetic and extra-diegetic readers, but it is far from an exclusively comic posture (287). Rather, as in the tradition of buffoon literature, it constitutes a purposeful performance in which self-abasement potentiates social criticism. Because Lázaro uses economic and legal terminology with a comic imprecision that, apparently unwittingly, defeats his ostensibly self-exculpatory purposes, the two economic episodes to which I now turn exemplify with particular clarity how this dynamic and the narrative tensions that arise from it operate in Lazarillo, while simultaneously demonstrating the text's satirical, ethically critical engagement with aspects of contemporary Castilian society to which it is generally thought to have been ideologically sympathetic. ${ }^{8}$

Therefore, my analysis seeks to take account of and harmonize three competing points of view within and about Lazarillo de Tormes. The first is internal to the text itself: that of Lázaro as the comically self-abasing yet 
satirical narrator-protagonist of his own life story. The second and third perspectives are external and concern two levels of Lazarillo's readership: that of the text's contemporaries, who were socially conditioned to read the character and his narrative in a particular fashion; and that of modern critics, whose sophisticated analyses of Lazarillo's subtlety and psychological nuance appear at odds with the reactions of those early modern readers for whom the text was actually written but that are, I contend, compatible with sixteenth-century notions of characterization and literary decorum.

There are two important references to monetary transactions in Lazarillo de Tormes, both of which occur in the tractado primero, when Lazarillo is in the service of his first master, the blind man. The first reference is the following:

Todo lo que [yo] podía sisar y hurtar traía en medias blancas, y cuando le mandaban rezar y le daban blancas [al ciego], como él carecía de vista, no había el que se la daba amagado con ella, cuando yo la tenía lanzada en la boca y la media aparejada, que, por presto que él echaba la mano, ya iba de mi cambio aniquilada en la mitad del justo precio. (Lazarillo 29)

Francisco Rico has analyzed this passage in detail, and his study will be the point of departure for my analysis. Although it was first published more than three decades ago, Rico's essay continues to shape analytical approaches to the use of economic terminology and its meaning in Lazarillo, and it is therefore still worth engaging in critical dialogue (Camps Perarnau 664-65). He points out that the word "cambio" in the cited passage has two possible meanings, both of them financial (Rico, "Resolutorio" 97-98). The first is as a monetary exchange of, for example, a high-value gold coin for fractional coins made of silver or copper. This was called in the period a cambio manual, cambio menudo, or trueque. The second possible meaning of "cambio" in this passage is that of cambio por letras, "un traspasso virtual del dinero" between markets via a bill of exchange or letra de cambio (Azpilcueta 39). I shall examine each of these cambios in turn.

First, however, there is another important term to consider in Lázaro's description, that of the "justo precio." The just price was either a price fixed by the relevant public authority or, in its absence, the estimación común or common market value of a good or service. While the moralists condemned any deceit in a commercial transaction that produced a deviation from the just price, civil law tolerated price fraud up to la mitad del justo precio, that is, a range of $50 \%$ to $150 \%$ of the just price. Any further 
deviance was classed as laesio enormis and conferred the right of restitution to the injured party. 9 Lázaro refers to this latitude in legally acceptable prices in his narrative, but, as we shall see, his use of moral, legal, and financial technicisms is imprecise.

Regarding the cambio manual, Rico alleges a contemporary controversy about the legitimacy of a moneychanger charging a fee for this service ("Resolutorio" IOо-or). In fact, such a debate hardly existed and in any case was of little theoretical importance, for practically all the Spanish moral philosophers (including the most important and influential) condoned both the exchange of coins and a moderate earning for the moneychanger. ${ }^{\text {Io }}$ The specific dispute to which Rico refers, between Juan de Medina on the one hand and Domingo de Soto and Martín de Azpilcueta on the other, was not about a fee for service but, rather, about the related yet distinct issue of whether a gold coin could command a commodity price in excess of its face value. Soto and Azpilcueta held that a gold coin could have a higher commodity price, while Medina insisted that it could not (Soto 3: 585-86; Azpilcueta 35-38). However, as Abelardo del Vigo's authoritative study demonstrates, Medina did not believe that charging a modest fee for the service of changing one coin for another was morally illicit (278-79, 349-50).

Rico contends that Lázaro's description of changing a blanca for a media blanca, "ya iba de mi cambio aniquilada en la mitad del justo precio," is a humorous adscription of a conservative theoretical position on monetary exchange: "el 'justo precio' de una blanca, en un cambio 'manual,' es ni más ni menos que una blanca" (Lazarillo 29; Rico, "Resolutorio" IOI). However, with regard to the cambio manual, no such "enfoque rigorista" as Rico identifies existed ("Resolutorio" IOI). The just price of such a cambio was not the face value of the coin(s) in question, but the fee that could licitly be charged for the exchange. A pragmatic of 1498 established just such legally binding tariffs:

Por quanto està por Nòs ordenado, y mandado, que ningunos cambiadores, ni otras personas que cambiaren monedas de oro en estos nuestros Reynos, y dieren por ella moneda de plata, o de vellon, no lleuen de troque y cambio por vn castellano mas de quatro marauedis, y de vn ducado, ò vna dobla tres marauedis, y de vn florin dos marauedis, y no mas. (Recopilacion 2: 5Ir; bk. 5, title I8, law 4)

Therefore, the maximum allowable price that a cambiador could charge for changing a castellano, for example, would be six maravedís (1.5 $\mathrm{x} 4$ ). This is a far cry from the 242.5 maravedís that would be equal to $50 \%$ of the coin's 485-maravedí official value, "la mitad del justo precio" in Rico's analysis. 
Bartolomé de Albornoz explains precisely this point in his Arte de los contractos of 1573. The cambiador may justly receive an "interesse" for his service, Albornoz asserts, "de donde esta claro, que no es parte del precio de la moneda que da, ni de la que recibe, como los Derechos que da[n] al Escribano por la Escriptura que haze, no son parte de la Escriptura, ni lo que se paga a el Iuez por la Firma de el Mandamiento, no es parte de el Mandamiento" (I24V-I25r). Charging one half of the value of the coin for a cambio manual, therefore, would be neither morally nor legally permissible. This is a point to which we shall return.II

Rico's assumption that the face value of a coin determined the just price of its exchange has important implications for his analysis of the second of our two cambios, the cambio por letras. These were unproblematic in and of themselves, as was charging a moderate fee for the service of issuing the appropriate letra de cambio, but they were frequently clandestine cambios secos, usurious "dry loans" in disguise. ${ }^{12}$ The historical context that Rico adduces for his analysis is the proclamation in $155 \mathrm{I}$ and $155^{2}$ of three decrees that prohibited charging for letras de cambio within Castile ("Resolutorio" IO4-06). According to Rico, prior to these edicts the just price of a letra de cambio was the total amount of money transferred plus the commission charged by the cambiador: "la cantidad en juego y el 'tanto de ganancia,' sumados, constituían el justo precio del cambio" ("Resolutorio" I07). Following the proscription of such a "tanto de ganancia" (Rico takes the phrase from Azpilcueta), he argues, the just price of any letra de cambio was reduced to the value of the letra itself, for which no fee could be charged.

For Rico, Lazarillo de Tormes again expresses a conservative theoretical position based on the denial of any legitimate profit from a cambio por letras: "La formulación rigorista de Lázaro supone que no puede haber ahí ganancia lícita: una blanca vale una blanca como quiera que se la haga correr" ("Resolutorio" I07). However, Rico also argues that, by saying that each blanca "iba de mi cambio aniquilada en la mitad del justo precio," Lázaro is subtly and cynically manipulating legal precepts in order to legitimize his theft:

Empieza contándonos cómo atesoraba "todo lo que podía sisar y hurtar"; describe luego los manejos con las blancas que recogía para el ciego; y acaba dejándonos con la impresión -o fingiendo creer que nos deja con la impresión- de que tales manejos no eran a su vez "sisa y hurto", sino una frecuentísima operación crediticia, discutible a ciertos propósitos, sí, pero en definitiva no condenable en derecho. Lazarus vindicatus. ("Resolutorio" IIO) 
I interpret the ultimate meaning of this episode differently. While I concur that Lázaro intends to imply that his petty thefts are analogous to "una frecuentísima operación crediticia" among cambiadores, the boy's monetary exchange would not be technically legal even if it were viewed as a cambio por letras, nor is it clear from Lázaro's narration of the episode itself that he is fully aware of the juridical regime governing bills of exchange in the first place. As in the case of the cambio manual, the just price of a cambio por letras was not the amount of the bill itself but the interesse or commission charged by the issuer. A pragmatic of 1534 set a maximum annual interest rate of $10 \%$, and cambiadores usually charged $2.5 \%$ for letras de cambio payable at the following Castilian merchant fair, in three months' time (González Ferrando 4-5). The prohibition on charging for letras de cambio within the kingdom, however, reduced the just price for such a contract to zero, although the merchant-bankers continued with their previous practices (Lapeyre 278). Thus, even if we accept that Lázaro means to insinuate, by analogy to the cambio por letras, that his own "cambio" conforms to civil law by only taking half of the blind man's alms ("la mitad del justo precio"), in reality it does nothing of the kind, for no fee whatsoever could be legally charged for any letras de cambio issued and payable within Castile (50\% of zero is zero). Lázaro's claim, therefore, would be akin to rationalizing an extortionate $50 \%$ commission through spurious legal reasoning, not a technical exculpation in conformity with the letter of the law. ${ }^{13}$

Rico also argues that, while the phrase "la mitad del justo precio" was proverbial but not widely understood, "Lázaro, desde luego, sí la entendía a derechas, aunque no vacilara en torcerla en provecho suyo" ("Resolutorio" I09). In view of his misapplication of the principle, however, and particularly because invoking the phrase does not function "en provecho suyo" in any legal sense, it is possible that Lázaro simply uses "la mitad del justo precio" with the same proverbial imprecision as did most of his contemporaries. In this reading, the phrase might well signify nothing more than Lázaro's jocularly self-justifying means of explaining how he was able to steal from the blind man. He does, after all, swap blancas for coins that are worth exactly half as much (medias blancas).14 At the narrative level, therefore, the episode of the medias blancas could plausibly function primarily in order to develop the incongruous (for modern readers) characterization of Lázaro as simultaneously guileful and gullible that Close identifies and sixteenth-century readers appear to have assumed: the ingenuity that he displays in outfoxing the blind man illustrates his craftiness, while his self-serving misuse of "la mitad del justo precio" demonstrates his comic foolishness. We could therefore speculate 
that he has merely heard the phrase advanced in similarly self-justifying circumstances by merchants and moneylenders, who deliberately veiled unscrupulous commercial and financial practices with verbal obfuscation.

From this perspective, Lázaro's point of view remains appropriately circumscribed within the generic imperatives of the literary work that he inhabits and responds to contemporary expectations of his comic nature. The character is thus reduced to a figure of fun whose pretensions to sophistication and self-exculpation are rendered comically ridiculous by the text's author. This potentially adversarial relationship between Lázaro and the implied author is consistent with a contest for narrative control that Edward Friedman has identified as a fundamental dynamic of Lazarillo de Tormes (42-43); it is also consonant with the historical author's possible view of the social and moral inferiority of the character, which Roncero López describes as both characteristic of Lazarillo and a basic attribute of Spanish picaresque fiction generally (56-57).

Nevertheless, to the degree that Lázaro's language in narrating this episode imitates the moral and legal contortions of contemporary cambiadores, the ironic disjunction between the character's words and his deeds does suggest a satire of the financial class, whose cambios are thereby implicitly censured as mere theft. As we have seen, it is consistent with the function of a professional buffoon to purposefully adopt an abject posture that is both self-degrading and very much self-conscious in order to disarm his readers (in this case, both Vuestra Merced and Lazarillo's assumed historical readership) with laughter while simultaneously satirizing morally censurable social (specifically, financial) practices. In this reading, Lázaro is entirely aware of his self-defeating distortion of "la mitad del justo precio," but his real purpose is to feign comic foolishness in order to imply that unscrupulous cambiadores are no more ethical in their actions, nor accurate in their legal manipulations, than he. Lázaro's description of how he exchanged blancas for medias blancas further develops this comically self-debasing yet satirical aspect of the narrative.

Lázaro tells us that he swapped blancas for medias blancas by kissing each blanca and surreptitiously exchanging it with one of the medias blancas that he carried in his mouth. The blanca was a fractional copper coin first minted in I497, whose value was one half of one maravedí (the standard unit of monetary account in the period). The issue is more complicated than it appears, however, because as María del Mar Royo Martínez reveals in her study of the numismatic references within Lazarillo de Tormes, no such coin as the media blanca was ever struck: "durante todo el siglo XVI no llegaron a labrarse en Castilla piezas de vellón que respondieran al nombre de media blanca" (226). Presumably, however, 
Lázaro does not make reference to an imaginary currency, so what coins is he referring to? Royo Martínez believes that Lazarillo's medias blancas were probably blancas del rombo, first coined in $\mathrm{I}_{47 \mathrm{I}}$ and reauthorized for circulation by royal decree in 1475 . The blancas del rombo had a nominal value of $1 / 3$ of one maravedí, but Royo Martínez speculates that they must have circulated with a slightly lower value of $1 / 4$ of one maravedi, making them, extra-officially, medias blancas (226-27). If this is true, then we can extrapolate no implicit monetary theory whatsoever from this episode, as Rico does. The critic's assertion that "una blanca vale una blanca como quiera que se la haga correr" cannot be the implicit theory underlying Lázaro's description of his cambio, because the character applies two different standards of evaluation to the coins that he names (Rico, "Resolutorio" 107). In the case of the blancas he is accepting them at their face value, while simultaneously valuing the so-called medias blancas according to their estimación común, that is, the commonly accepted value at which they actually circulated. One might argue that the estimación común determines the value of both coins, and that the common estimate coincides with the face value of the blancas but not that of the medias blancas. This is precisely the opposite of Rico's contention, but assuming that Lázaro values coins according to their estimación común is the only way to extract any coherent monetary theory from his story. Even so, I do not believe that the text supports any such specific theoretical posture. Instead, we must locate a more symbolic meaning.

In fact, just such a meaning is on hand. Lázaro says of the blind man: “También él abreviaba el rezar y la mitad de la oración no acababa, porque me tenía mandado que, en yéndose el que la mandaba rezar, le tirase por cabo del capuz" (Lazarillo 30). Here is the correlation: the medias blancas that Lazarillo slips to the blind man are the equivalent of the medias oraciones that his master recites, and the symbolic connection between the words and the coins is reinforced by the fact that the boy hides the money in his mouth. Therefore, through his petty theft, Lazarillo quite inadvertently pays the blind man the just price for his half prayers. This constitutes an ironic act of rough justice, for the scholastic moral philosophers (then in preeminence in Castile) held that commutative justice, as a precept of natural law, required absolute equality of exchange in any transaction, independently of the persons involved or their motives.15 Lazarillo's intention is certainly not to give the blind man his due for shorting the almsgivers, but that is irrelevant to the just result of his self-interested action. 
Y la razón es porque como la rectitud de la justicia se halle naturalmente en las cosas mismas, quien paga lo debido con intención y fines torcidos, no deja de ejecutar un acto justo al dar a otro lo que le pertenece, si bien él no puede llamarse justo, esto es, virtuoso, puesto que no obra cuando, en donde y como conviene.

(Soto 2: 192-93)

Once again, at the narrative level the primary thrust of the story is comic and stems from the ironic justice with which the blind man gets his comeuppance at the hands (and mouth) of his young charge. However, the explicit connection between words, coins, and justice established in the episode imbues Lázaro's story with a satirical perspective on the class of newly affluent merchant-bankers, whose financial practices, the incident suggests, are little more than unsophisticated acts of theft self-servingly justified through the deliberate misapplication of a serious moral principle. ${ }^{16}$ Conceptually, this is the payoff to Lázaro's self-justifying distortion of the phrase "la mitad del justo precio," and it lends credence to the argument that the character has indeed crafted this story so as to cast himself as an ironic instrument of justice within a degraded society. Such guilt-by-association techniques were typical of sixteenth-century buffoons, particularly in relation to their Jewish origins (Roncero López 49-50). Thus, while the episode of the medias blancas is first and foremost a comic incident at the narrative level, the text is saturated with an irony that modulates the episode's satire away from the expected mockery of a lowborn character and toward the critique of financial malfeasance dressed up as moral righteousness. This profoundly ambiguous matrix of comedy, irony, satire, and shifting narrative perspectives is further developed in the episode of the sausage and the turnip.

In this instance, Lazarillo effects another swap, this time not of coins but of a turnip for the sausage that the blind man is preparing. A cluster of critical terms associates this exchange with the financial cambios. The first clue comes when Lazarillo is sent to fetch wine, as he relates: "Yo fui por el vino, con el cual no tardé en despachar la longaniza" (Lazarillo 39). The key word in this description is "despachar," for which Sebastián de Covarrubias gives three definitions: "I. Salir de empacho y de embarazo. 2. Algunas veces vale matar. 3. Enviar correo con cartas" (4I7). The third meaning is applicable in this case, as we shall see. When the blind man discovers the trick, Lazarillo protests his innocence in financial terms: "Yo torné a jurar y perjurar que estaba libre de aquel trueco y cambio" (Lazarillo 39). This, then, is a two-part operation: first the "trueco" of turnip for sausage and then the "cambio" proper, a metaphorical dispatching of a bill of exchange. ${ }^{77}$ As Rico explains, "ahí, en el capítulo 
primero, después de la historieta de las medias blancas, 'trueco y cambio' no es una pareja de sinónimos, sino una gradación de dos palabras afines, que en la página siguiente culmina con una tercera más gruesa: 'hurto'" ("Resolutorio" 96n6). ${ }^{18}$ I agree, but, as in the case of the medias blancas, the episode's comic and satirical registers operate on separate but contiguous levels of referentiality. In the pragmatic of 1498 cited above, the phrase "troque y cambio" is used in explicit reference exclusively to the cambio manual, while in a text roughly contemporaneous with Lazarillo de Tormes, Álvar Núñez Cabeza de Vaca likewise describes as a "cambio y trueco" the (non-monetary) exchange of seashells for pelts and red ochre among Native Americans (133). Therefore, Lázaro could be understood to use the terms "trueco y cambio" not as a description of separate credit operations on a scale of increasing financial complexity, nor even as a pair of synonyms, but merely as a single phrase that simply equates to "exchange." On the other hand, as Rico asserts, in this passage the text plausibly establishes a gradation from "trueco" to "cambio" to "hurto." Tomás de Mercado indicates that the word hurto was commonly associated with unscrupulous financial dealings, for instance, when he writes that "muchos doctores llaman la usura hurto y al usurero, ladrón" (2: 539). Thus, while on one level Lázaro only refers directly to pinching a meal from the blind man, in keeping with the comic aspect of the continuing battle of wits between master and servant, the economic subtext, which by this point in the tractado primero is substantially developed, connects the boy's innocuous hurto with the large-scale legal infractions that were commonly attributed to contemporary cambiadores. ${ }^{19}$

The episode's economic metaphor is extended and developed when the blind man thrusts his nose down the boy's gullet in search of the missing sausage:

Y con esto, y con el gran miedo que tenía, y con la brevedad del tiempo, la negra longaniza aún no había hecho asiento en el estómago; y lo más principal: con el destiento de la cumplidísima nariz medio cuasi ahogándome, todas estas cosas se juntaron y fueron causa que el hecho y golosina se manifestase y lo suyo fuese vuelto a su dueño. (Lazarillo 40)

The word "asiento" appears to function here on two levels. At the level of plot, it means no more than that the sausage had not settled in Lázaro's stomach. However, a secondary meaning, which is justified by the general context of financial terminology in the episode, further develops the text's satirical posture toward merchant-bankers. In this sense, "asiento" refers 
to the entry of a monetary sum in a banker's ledger. For example, a pragmatic of 1549 uses the term assentar to establish rules governing commercial accounting in Castile:

Mandamos, que de aqui adelante todos los bancos, y cambios publicos, y los mercaderes, y otras qualesquier personas ... sean obligados a tener, y assentar la quenta en lengua Castellana en sus libros de caxa, y manual, por deue, y ha de auer, por la orden que los tienen los naturales de nuestros Reynos, assenta[n]do el dinero que recibieren, y pagaren, declarando en que moneda lo reciben y pagan. (Recopilacion 2: 52v; bk. 5, title I8, law Io; emphasis added)

Lázaro's use of the verb manifestarse suggests a similar double meaning. In Covarrubias's definition the word means "Declarar aquello de que no se tenía noticia," and a manifestación is simply a "Declaración" (733). At the level of comic incident, Lázaro uses the word in this non-technical sense, as the blind man receives an unexpected "declaration" of the sausage's whereabouts. A secondary meaning of manifestarse indicates a legal context, however, because disputed objects in a lawsuit were held de manifiesto by a third party designated by the judge (Cervantes 569; pt. I, ch. 44). A further possible subtext is the scholastic theory of money as being, like wheat and wine, a fungible good that is figuratively consumed in its use. This was the ideological basis for the prohibition of usury, because a monetary loan (mutuum) was held to be a temporary transfer of ownership to the recipient, who then consumed the coins by spending them. ${ }^{20}$ Thus, the passage is a complex linguistic palimpsest of common words and technical terminology that ultimately describes a satirically degraded litigation in which the consumed sausage/money is returned "a su dueño" in an act of comically grotesque restitution.

As in the medias blancas episode, the text's satirical content is secondary and is potentiated by specialized knowledge of moral philosophy and financial and legal practice. At the level of plot, however, and in keeping with the comic nature of the narrative (often based upon witty double meanings), the incident turns on a pun upon the word "trueco." Then as now, the verb trocar meant not only "to exchange" but also "to vomit" (Covarrubias 937; Contreras 134-35). That is exactly what happens in the episode, as Lazarillo's initial "trueco" (turnip for sausage) is repeated, in comically degraded form, with a foul smelling "trueco" in the blind man's face. Because the words "trueco" and "cambio" occupied the same semantic field and could refer, separately or together, to exactly the same exchange, Lázaro humorously links both terms in his wordplay on trocar (cambiar/vomitar). At the level of social satire, however, the episode 
suggests that cambiadores illicitly consume their clients' funds through the usurious interest on their cambios.

The double action of the scatological cambio, ingestion/devolution, extends this satire through its mocking reference to the cambiadores' methods of profiting illegally from usurious recambios. These were fraudulent letras de cambio issued either without covering funds or to fictional factores (business associates) abroad. The bills were therefore intentionally unpayable upon receipt, and they caromed between financial markets, accruing interest (Lapeyre 28I-86; Mercado 2: 430-46). Luis Saravia de la Calle includes in his Instrucción de mercaderes of 1544 a chapter "De los cambios secos, cuya malicia e industria es notoria," in which he summarizes both the workings of the recambio as well as the issues of financial immorality and the widespread condemnation of the consumption of unwitting victims by usurers that we have identified in Lazarillo de Tormes:

Y para aqueste efecto envían las pólices a Flandes y a Sevilla a su factor; el cual allá hace sus diligencias de buscar al factor del mercader al cual va dirigida la cédula, sabiendo que no le ha de hallar; y hace sus requerimientos y protestos y toma a cambio en nombre del pobre mercader; y envía luego el dicho testimonio de a cómo valían los dineros en Flandes o en Sevilla. Y todo va sobre la capa del mercader, y así como a sanguijuela le chupan la sangre sin sentirlo. (I77-78)

The point of application to our passage in Lazarillo is the following: after performing the "trueco" with the turnip, Lazarillo dispatches his metaphorical "cambio" by consuming the sausage, which then becomes a recambio when it returns to its legitimate owner with repugnant interest.

The language of consumable money is obviously metaphorical, and it was understood to be so by the moralists of the period. As Luis de Molina explains:

Se entiende por consunción también la enajenación del bien debido a su uso, como el dinero cuando con él se paga algún bien, se cambia por otra clase de dinero, o se entrega en donación o préstamo; en esos casos se dice que se consume por referirnos al que lo entrega, ya que al entregarlo traspasa su dominio a otra persona. (IO-II)

Nevertheless, such terminology was widespread not only in ecclesiastical authors (e.g. Saravia de la Calle), but in humanist and political sources as well. For example, the Erasmian Diego Gracián, translator and secretary to Emperor Charles V, wrote a memorial "sobre que las vsuras e interesses 
cambios y recambios tienen chupada y consumida y chupan y consumen el Patrimonio Real y la sustancia de los Reinos y provinçias de España y otras" (44r). Gracián penned the memorial "de xl años a esta parte que a que esta en seruiçio de su magestad," which makes it almost exactly contemporaneous with the publication of Lazarillo de Tormes (48v). The political economists of the early seventeenth century, the so-called arbitristas, continued to use similar language in a sometimes apparently literal way, as a means of strengthening their arguments or disparaging those of their rivals. Gaspar de Pons, for example, insists that if the Crown institutes the correct monetary policy, "en cada prouincia se podra siempre tener la abundancia y largueza de moneda que conuenga, mayormente siendo cosa que no se consume (como sin duda lo esta)" (Tratado $38 \mathrm{v}$ ). ${ }^{21}$ Martín González de Cellorigo, for his part, argues that

la verdadera riqueza no consiste en tener labrado, acuñado o en pasta, mucho oro y mucha plata, que con la primera consunción se acaba, sino en aquellas cosas que aunque con el uso se consumen, en su género se conservan por medio de la subrogación con que se puede sacar de las manos de los amigos y enemigos el oro y la plata. (69)

Lope de Deza, in his condemnation of usury, also recurs to the same metaphorical language: "llamó bien el otro poeta a la usura, tragadora e insaciable" (55). Deza clearly understood the poetic nature of this language, as, I would argue, did the author of Lazarillo de Tormes, who literalized it in superbly literary fashion in order to infuse a comically scatological scene based upon folkloric and buffoonish antecedents with a satirical perspective on the realities of financial practice in contemporary Castile.

The episodes of the medias blancas and the sausage and turnip develop a satirically censorious perspective on the greed and immorality of the merchant-bankers that is entirely in keeping with contemporary attitudes. The influx of unprecedented amounts of silver from the American colonies in the sixteenth century fostered the creation of speculative currency markets and made possible the enrichment of a specialized group of merchants and financiers capable of profitably exploiting them. The rise of a nouveau-riche commercial class, in turn, spurred a disconcerting amount of social churn and aroused the Church's traditional suspicion of non-inherited wealth.22 This perspective is evident in Cristóbal de Villalón's robust rejoinder to those cambiadores who defended the necessity of providing credit and facilitating trade: " 0 infelices de vosotros $\mathrm{q}[\mathrm{ue}]$ de vuestra cobdicia y auaricia y soberuia ha nascido essa necessidad q[ue] fingis, por que enla verdad ninguna 
necessidad tiene la republica $\mathrm{d}[\mathrm{e}]$ vosotros, $\mathrm{a}[\mathrm{n}]$ tes le soys total perdida y destruyción" (IXr). Villalón further alleges that the cambiadores rend the very social fabric of the republic by gobbling up the patrimony of the nobility: "apocays y d[i]smenuys la nobleza $\mathrm{d}[\mathrm{e}]$ la republica necessita[n]do los a todos con vuestras vsuras. ... E no sienten los desuenturados el veneno de vuestra maldad hasta q[ue] veen comidos y $\mathrm{q}$ [ue] para pagaros es necessario ve[n]der sus mayorazgos propios y rentas q[ue] sus padres les d[e]jaron" (IXr). ${ }^{23}$ Again we encounter the traditional charge that moneylenders consume their victims through their illicit financial practices, just as is suggested in the episode of the sausage and turnip in Lazarillo.24

Such sanguijuelas (to use a term widespread in the period and employed by Saravia de la Calle in a passage cited above), were unlikely to be concerned about the less fortunate. To appeal to their self-interest, the moralists applied economic language metaphorically in order to condemn neglect of the marginalized and enjoin charity. Juan de Robles, who in 1545 held a debate in print with Soto over the appropriate means of dealing with the indigent, compares charity to a letra de cambio: "digo que es como quien libra o paga en cambio, que da los dineros en Medina y con una cédula de cambio recibe su dinero en Roma. Así Dios tiene su compañía y cuenta con lo que en este mundo se da a los pobres: recibe el pobre el dinero y libra en Dios para el cielo" (196).25 Mercado likewise calls charity "la [usura] del Cielo que Dios promete" (2: 525). Almost half a century after the publication of Lazarillo de Tormes, Mateo Alemán gave voice to the same concepts in Guzmán de Alfarache: "Desata las [manos] tuyas en favorecer los mendigos, que es tu interese y te va más a ti en darlo que a ellos en recebirlo. No hizo Dios tanto al rico para el pobre como al pobre para el rico" (42I).

The use of economic terminology in the episodes of the medias blancas and the sausage and turnip suggests that Lazarillo de Tormes responds critically to this social context by satirizing contemporary cambiadores for their greed and moral hypocrisy in distorting civil law and ethical precepts in order to justify financial practices that amounted to little more than blatant thievery. Nevertheless, the precise nature of that satirical discourse and the degree to which sixteenth-century readers might plausibly have perceived it remains speculative. As Rico observes:

¿Lazarillo procede como un "cambiador", los cambiadores proceden como Lazarillo, todos actúan por un igual? Los profesionales espulgaban las costuras de leyes y cánones para justificar el negocio de los cambios; al imitarles Lázaro, ¿se disculpa a sí mismo o les inculpa a ellos? Las medias blancas que hacían posible su modesta 
rapiña las allegaba el destrón a fuerza de "sisar y hurtar"; el capital con que traficaban los cambiadores ¿tenía orígenes más honrados? Son preguntas que Lázaro sugiere y, claro, deja sin contestar. ("Resolutorio" III)

A question naturally arises in view of this ambiguity: why is Lazarillo so circumspect in its presentation and criticism of financial malfeasance? As we have seen, in mid-sixteenth century Castile there was no shortage of moralists willing to explicitly condemn economic immorality of the kind to which the novel merely alludes. The answer, I contend, is to be found in the principle of literary decorum, which prescribed the comic nature of the pícaro and the kind of humour in which he could engage (Close 285; Roncero López 56). Lázaro is not a moralist, and he lacks all legitimacy for sermonizing; contemporary readers were socially conditioned to treat his every word with a humour born of class-based contempt (Chevalier 17576). What, then, of the example of Guzmán de Alfarache, in which the narrator-protagonist, proverbially called el Pícaro, repeatedly indulges in open sententiousness and moralizing? This was a problem that Alemán confronted directly but never fully resolved:

Again and again, Guzmán anticipates the reader's potential objections to being preached at by a lowly pícaro and galley slave; the apologies, often wryly humorous, merely result in ad hoc suspension of the sermon, never its curtailment in principle, for the good reason that this is the essential purpose of the book. (Close 289)

Similar to Góngora's Polifemo and Soledades and Lope de Vega's comedias, Guzmán de Alfarache was controversial precisely because of its violations of literary decorum (Close I2I). In contrast, Chevalier cites evidence that contemporary readers appreciated precisely the propriety of Lazarillo's language and the characterization of its protagonist (176-77).

Reading Lazarillo de Tormes within the context of contemporary buffoon literature resolves the tension between the text's comic and satirical matrices. If we attribute to Lázaro the characteristics of a professional buffoon, as do Márquez Villanueva and Roncero López, then his apparently inadvertent self-incrimination through the imprecise use of terms such as "la mitad del justo precio" in the medias blancas episode serves a dual purpose. On one level it makes the character the butt of ridicule for his apparently inept use of moral and legal language in his failed attempt at self-exculpation. As we have seen, it is not necessary to attribute precise knowledge of financial terms and concepts to him, as Rico does, in order to explain his references to contemporary cambiadores; the 
language that Lázaro uses was widespread and could be employed in a relatively non-technical register appropriate to the protagonist of a work of pure comedy. If, however, Lázaro functions in the guise of a professional buffoon, then in the two economic episodes that we have analyzed the comic imprecision of his language is, in fact, a carefully calculated performance, a self-degrading posture purposefully adopted to induce laughter in his readers at his own expense, thus enabling this low-born, marginalized character to express an otherwise incongruous satire of the financial class for their fiscal malfeasance. This interpretation is not consonant with the view that Lazarillo expresses a proto-bourgeois ethic in support of nascent capitalism, but it is consistent with the, perhaps paradoxical, social conservatism of buffoon literature, which, we recall, was intended for an aristocratic readership and illustrates the buffoon's ability to advance socially through the manipulation of a hierarchical system (Roncero López 69). This ironically bifurcated point of view, between self-incriminating comedy and self-degrading social satire, is analogous to the medias blancas episode, in which the boy simultaneously commits a conscious act of theft and an unintended act of justice. If Lazarillo puts his money where his mouth is, Lázaro uses irony, humor, and satire to put his mouth where the money is.

Trinity College Dublin

\section{NOTES}

I See Beverley, Molho, Rodríguez (II5-205), Sánchez, and Folger. Maiorino argues that entrenched class interests impede Lázaro's efforts to become a legitimate wage earner, so he instead invests in the education that allows him to level a counter-indictment against society for his own transgressions. Camps Perarnau's "fiscal" reading, which most closely accords with my own analysis, interprets Lazarillo as a satire of the ironically-named hombres buenos, members of the urban oligarchy who sought to rise socially at the cost of the masses by exploiting preferential fiscal policies.

2 Edward Friedman, in contrast, posits that "A key component of any inquiry [into Lazarillo] ... will be the positioning of Lázaro in relation to an implied author" (40). Other critics have perceived a partial or intermittent disjunction between the author's point of view and that of the text's narrator protagonist. See Asensio (85); Sobejano (IO); and Spadaccini (2IO-II).

3 The reference to the paradigmatic "simplezas en Lázaro" in the "Prólogo sumario" of La pícara Justina illustrates how early modern readers perceived 
Lázaro as the foolishly naïve protagonist of a work of comic entertainment (López de Úbeda ir6). Close points out that "in both sequels to Lazarillo (Antwerp, 1555; Paris, 1620), Lázaro is flabbergasted to discover his wife's infidelity" (286ni5). The ability to tell good stories skillfully was a hallmark of professional buffoons (Roncero López 78-79).

4 Lázaro Carreter believes that in Lazarillo the "artificio vetustísimo" of narrative symmetries is put in the service of "algo rigurosamente moderno y característico de la novela," i.e. the failure of the hero (95).

5 A passage in Don Quijote, Part I provides evidence in support of Close's argument. In the interpolated novella "El curioso impertinente," Lotario implores Anselmo not to test the virtue of his wife, Camila: "el marido de la mujer adúltera, puesto que él no lo sepa, ni haya dado ocasión para que su mujer no sea la que debe, ni haya sido en su mano ni en su descuido y poco recato estorbar su desgracia, con todo le llaman y le nombran con nombre de vituperio y bajo, y en cierta manera le miran los que la maldad de su mujer saben con ojos de menosprecio, en cambio de mirarle con los de lástima, viendo que no por su culpa, sino por el gusto de su mala compañera está en aquella desventura" (Cervantes Don Quijote I, 423). Lázaro would find little sympathy among his contemporaries for being an unwitting cuckold, and being a cornudo consentido would bring only moral opprobrium and social ostracism of the kind that no one would deliberately invite.

6 Chad Leahy makes the same point in his study of laughter in Lazarillo: "La constante risa del Lazarillo es polivalente y debe actuar tanto como agente de crítica social como manifestación del humor folclórico y carnavalesco que caracteriza sus páginas" (338).

7 Roncero López does, however, make reference to the conjunction of the discourses of economics and buffoonery in Guzmán de Alfarache (IO4-05).

8 In drawing this distinction I do not mean to throw the baby out with the bathwater. I do not question the context of the structural socio-economic changes within which critics such as Beverly and Molho place Lazarillo de Tormes. "Es un hecho probado que durante la fase de ascenso de la economía española que transcurre de mediados del siglo xv a finales del xvi las relaciones crediticias se intensificaron, respondiendo así, con la suficiente largueza y elasticidad, a las necesidades de la economía productiva y del creciente comercio" (Marcos Martín I38). Rather, I argue that Lazarillo's engagement with this context suggests, not acceptance or celebration, but moral critique of evolving commercial and financial practices within a newly fluid economy that were widely perceived to be unethical.

9 Recopilacion (2: 27r; bk. 5, title II, law I); Soto (3: 549-53); Mercado (I: I42-54).

IO Lapeyre (228); Vigo (276-85, 349-5I); González Ferrando (20). 
II There were a number of terms used to describe moneychangers in sixteenthcentury Castile, including cambio, banco, and banquero. The oldest term was cambiador, which appears in the above-mentioned pragmatic of I498. However, cambiador came to describe the merchant-bankers who issued letras de cambio, as well. Azpilcueta and Villalón use the term in this way. The modern term cambista did not yet exist (Lapeyre 217-I8).

I2 Villalón (XVIv-XVIIIv); Soto (3: 583-84); Azpilcueta (I7-20, 39-47); Mercado (2: 396-4IO).

I3 I do not mean to argue that this episode justifies holding Lazarillo morally accountable for stealing medias blancas from the blind man, even by the standards of the period; sixteenth-century moralists recognized that the threat of starvation legitimizes theft (Soto $3: 428$ ).

I4 Rico similarly argues that Lázaro's phrasing, "ya iba de mi cambio aniquilada en la mitad del justo precio," is significant because it purposefully references the technical language of scholasticism: "El giro común hablaba de 'engañar en la mitad del justo precio'; Lázaro emplea un 'aniquilar' más neutro, con la asepsia del lenguaje filosófico ... que desvía la atención de la anécdota ruin, disuelve en generalidad el dato particular" ("Resolutorio" I09). Nevertheless, contemporary usage of the verb aniquilar was not limited to philosophical discourse. Rather, it formed part of the language of political economy, as well. In a text nearly contemporaneous with Lazarillo, Memorial del contador Luis Ortiz a Felipe II (1558), the controller (accountant) from Burgos Luis Ortiz enumerates a list of proposals to impede capital flight from Castile: "Lo primero que se deroguen las leyes del Reino por las cuales están los oficiales mecánicos anichilados y despreciados" (32; emphasis added). Lázaro’s use of aniquilar is therefore not necessarily as technically precise as Rico contends.

I5 Soto (2: 192-93, 240-49); Azpilcueta (25-26); Mercado (r: 49-50). The just price was normally referenced with regard to the price of goods in commercial exchanges, but the principle was equally applicable to labor contracts. Soto, for example, considers whether lawyers may justly charge a fee for the defense of their clients. He concludes that they may, provided that the amount charged does not exceed the just price (3: 478).

I6 There was no clear distinction between the merchant-bankers' mercantile and financial activities. Their profits appeared to be immoral and their financial practices were largely incomprehensible to contemporary observers (Lapeyre 218-19; Ortiz 134-35).

I7 Despachar was not normally used to describe the issuance of a letra de cambio, tomar a cambio being the correct phrase. However, the very imprecision of the term is congruent with Lázaro's comic characterization and his (purposefully) imprecise use of economic vocabulary. 
I8 The use of the term 'hurto' to which Rico refers occurs when the blind man sticks his nose in the boy's mouth in an effort to sniff out the missing sausage: "De manera que, antes que el mal ciego sacase de mi boca su trompa, tal alteración sintió mi estómago, que le dio con el hurto en ella, de suerte que su nariz y la negra mal maxcada longaniza a un tiempo salieron de mi boca" (Lazarillo 40).

I9 "Y el decir todos que los cambiadores son usurarios es argumento evidente de serlo, porque la voz y sentencia común del pueblo, dicen que es voz y sentencia divina, que no puede falsearse" (Mercado 2: 363).

20 Grice-Hutchinson (28-29); Soto (2: 370; 3: 509-10); Mercado (2: 516-I8, 525-36).

2I This long and compendious memorial, dated in Madrid, i9 September I600, is not titled, but it is catalogued in the Goldsmiths'-Kress database as Tratado sobre la Real hacienda. While the document is anonymous, it is indisputably the work of Gaspar de Pons. It is, in large part, an expansion of point number seven of the Diez puntos, another memorial written by Pons that dates from 1599. It also includes somewhat altered versions of at least two other memorials by Pons, the Medios propuestos of 1595 (reproduced in Sempere y Guarinos XLIII-LIV] and a manuscript titled Expos[ici]on de io puntos q[ue] se tocaron en Villete q[ue] se embio al Rey N[uest]ro s[eñ]or D[on] Ph[elip]e $3^{-}$año 1599. The Biblioteca Nacional de España contains a copy of the first page of the Tratado, catalogued under the title Señor, En vn billete y papel q[ue] embie a V.M. de data de 15 de otubre de 1599, but not the entire document. The Tratado was probably printed at the Imprenta Real in Madrid. For this latter detail I am grateful to Professor Don W. Cruickshank, who generously shared his time and expertise in early modern Spanish print culture. I cite the Tratado from the Goldsmiths'-Kress microfilm, which reproduces a copy of the document held by Harvard University. On Pons, one of the most important and prototypical of the early arbitristas, see Vilar (178-79) and Grice-Hutchinson (134-35).

22 In making this assertion I certainly do not intend to dredge up hoary notions of the Black Legend. Nevertheless, it is a fact of intellectual history that what we today call economic theory was, in the early modern period, essentially medieval in orientation, i.e. normative (not descriptive) and reflective of largely unchallenged social structures. See Vigo (227) and Lapeyre (295).

23 Villalón's Prouechoso tratado de ca[m]bios was the first such treatise written in Castilian. Its popularity is attested by that fact that it was published in five separate editions in 154I (Valladolid), 1542 (Valladolid and Seville), and I546 (Valladolid and Córdoba) (Vigo I04). See also Reeder and D’Emic.

24 This kind of rhetoric remains widespread, as in Matt Taibbi's now-famous description of investment bank Goldman Sachs as "a great vampire squid wrapped around the face of humanity, relentlessly jamming its blood funnel into anything that smells like money." 
25 I am not concerned here to draw a distinction between the Dominican Soto and the Benedictine Robles regarding the appropriate means of succoring the poor. Despite their differences, the two men agreed upon the duty of giving charity. For an application of the debate between Soto and Robles to the theme of charity in Lazarillo de Tormes, see Cruz (2I-29).

\section{WORKS CITED}

albornoz, в artolomé de. Arte de los contractos. Valencia: Pedro de Huete, I573.

A Le mán, mate o. Guzmán de Alfarache I. Ed. José María Micó. 6th ed. Madrid: Cátedra, 2003.

ASENSIO, MANUE L J. "La intención religiosa del Lazarillo de Tormes y Juan de Valdés." Hispanic Review 27.I (I959): 78-IO2.

AZP Il C UE TA, MAR Tín DE. Comentario resolutorio de cambios. Eds. Alberto Ullastres, José M. Pérez Prendes, and Luciano Pereña. Madrid: Consejo Superior de Investigaciones Científicas, 1965.

Beverley, jo hn. "Lazarillo and Primitive Accumulation: Spain, Capitalism and the Modern Novel." The Bulletin of the Midwest Modern Language Association I5.I (1982): 29-42.

CABEZA DE VACA, Álvar nú ÑEZ. Naufragios. Ed. Juan Francisco Maura. 9th ed. Madrid: Cátedra, 20 IO.

CAmps PeRARnau, susana. "Propuesta de lectura fiscal del Lazarillo de Tormes."

Bulletin Hispanique 113.2 (2011): 663-99.

Cervantes, mi gue l De. Don Quijote de La Mancha. Ed. Francisco Rico. 2 vols.

Barcelona: Galaxia Gutenberg/Círculo de Lectores/Centro para la Edición de los Clásicos Españoles, 2004.

CHEVALIER, MAXI M E. Lectura y lectores en la España de los siglos XVI y XVII. Madrid:

Turner, 1976.

C L ose, an th ony. Cervantes and the Comic Mind of His Age. Oxford: Oxford UP, 2002.

contreras, alonso De. Discurso de mi vida. Ed. Henry Ettinghausen. Barcelona: Bruguera, 1983 .

COVARRUBIAS OROZCo, SEBASTIÁN DE. Tesoro de la lengua castellana o española.

Ed. Felipe C. R. Maldonado. Rev. ed. Manuel Camarero. Madrid: Castalia, I995.

CRUZ, AN NE J. Discourses of Poverty: Social Reform and the Picaresque Novel in Early

Modern Spain. Toronto: Toronto UP, I999.

D'E M IC, M ICHAE L. "Market Liberalism and Antiliberalism in Spanish Late Scholastic

Treatises (154I-1547)." Journal of Markets and Morality I5.I (2012): I6I-77. 
D EZA, LO PE DE. Gobierno político de agricultura. Ed. Ángel García Sanz. Madrid: Instituto de Cooperación Iberoamericana/ Sociedad Estatal Quinto Centenario/ Antoni Bosch editor/ Instituto de Estudios Fiscales, I99I.

F O L GER, R O BE RT. Picaresque and Bureaucracy: Lazarillo de Tormes. Newark: Juan de la Cuesta, 2009.

FRIED man, ED WAR D H. Cervantes in the Middle: Realism and Reality in the Spanish Novel from Lazarillo de Tormes to Niebla. Newark: Juan de la Cuesta, 2006.

FRY E, NO RT H R OP. The Secular Scripture: A Study of the Structure of Romance. Cambridge: Harvard UP, 1976.

gONZÁLEZ De CELLORIg O, MARTín. Memorial de la política necesaria y útil restauración a la república de España y estados de ella y del desempeño universal de estos reinos (16oo). Ed. José L. Pérez de Ayala. Madrid: Instituto de Cooperación Iberoamericana/Sociedad Estatal Quinto Centenario/Antoni Bosch editor/ Instituto de Estudios Fiscales, I99I.

GONZÁleE FERRANDo, JosÉ MARía. “La idea de 'usura' en la España del siglo XVI: Consideración especial de los cambios, juros y asientos." Pecunia. Revista de la Facultad de Ciencias Económicas y Empresariales, Universidad de León 15 (2012): $\mathrm{I}-57$.

GRACIÁN, Diego. "Memorial del secretario Diego Gracian criado de Su Mag[esta]d." MS 673r. Biblioteca Nacional de España. 44r-49r.

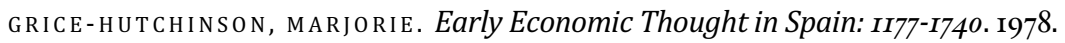
Abingdon: Routledge, 2012.

GUILlÉN, C LAUdio. "La disposición temporal del Lazarillo de Tormes." Hispanic Review 25.4 (1957): 264-79.

LAP eyre, hen r. Una familia de mercaderes: Los Ruiz. Contribución al estudio del comercio entre Francia y España en tiempos de Felipe II. Trans. and ed. Carlos Martínez Shaw. Valladolid: Junta de Castilla y León Consejería de Cultura y Turismo, 2008.

LAZARILLO DE TORMES. Ed. Francisco Rico. 2oth ed. Madrid: Cátedra, 2008. LÁZARO CARRETER, FERNANDO. Lazarillo de Tormes en la picaresca. 2nd ed. Barcelona: Ariel, 1983.

LEAHY, CHAD. "Y rió mucho la burla': Nuevos apuntes sobre la risa en el Lazarillo." Romance Notes 45.3 (2005): 329-38.

LóPEZ De úbeda, FRAncisco. La pícara Justina. Ed. Luc Torres. Madrid: Castalia, 2010.

maio rino, giancarlo. At the Margins of the Renaissance: Lazarillo de Tormes and the Picaresque Art of Survival. University Park: The Pennsylvania State UP, 2003 .

marcos martín, alberto. España en los siglos XVI, XVII y XVIII: Economía y sociedad. Barcelona: Crítica, 20oo. 
MÁRqUEZ VillanUEva, FRANCiSco. "Literatura bufonesca o del 'loco."” Nueva

Revista de Filología Hispánica 34.2 (1985-86): 50I-28.

mer Ca do, t o m Ás D E. Suma de tratos y contratos. Ed. Nicolás Sánchez-Albornoz. 2 vols. Madrid: Instituto de Estudios Fiscales Ministerio de Hacienda, 1977.

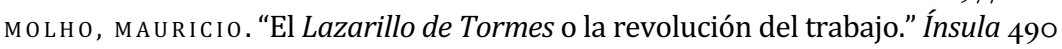
(I987): 2I-22.

—. "El pícaro de nuevo." MLN I00.2 (1985): 199-222.

Mo L INA, LUiS DE. Tratado sobre los préstamos y la usura. Ed. Francisco Gómez Camacho. Madrid: Instituto de Cooperación Iberoamericana/Sociedad Estatal Quinto Centenario/Instituto de Estudios Fiscales, 1989.

o R T IZ, Lu IS. Memorial del contador Luis Ortiz a Felipe II. Ed. José Larraz. Madrid: Instituto de España, I970.

pons, GASPAR DE. Diez puntos. 1599. TS. VE/28/26. Biblioteca Nacional de España, Madrid.

-. Expos[ici]on de io puntos q[ue] se tocaron en Villete q[ue] se embio al Rey N[uest]ro s[eñ]or D [on] Ph[elip]e $3^{\circ}$ año I599. 1599. MS 2346. Biblioteca Nacional de España, Madrid. 63r-159r.

-. Señor, En vn billete y papel q[ue] embie a V.M. de data de 15 de otubre de 1599. I599. TS. VE/210/82. Biblioteca Nacional de España, Madrid.

-. Tratado sobre la Real Hacienda. Madrid: I6oo. Microform. Goldsmiths'-Kress Library of Economic Literature: reel 38, number 297.4-I.

Recopilacion de las leyes destos reynos, hecha por mandado de la Magestad Catolica del Rey don Felipe Segundo nuestro señor; que se ha mandado imprimir, con las leyes que despues de la vltima impression se han publicado, por la Magestad Catolica del Rey don Felipe Quarto el Grande nuestro señor. 3 vols. Madrid: Catalina de Barrio y Angulo y Diego Diaz de la Carrera, i640. Facsim. Valladolid: Lex Nova, I982.

REEDER, JоH N . “Tratados de cambio y de usura' en Castilla (I54I-I547).” Hacienda Pública Española 38 (1976): I71-77.

Ric 0, FRAn Cisco. La novela picaresca y el punto de vista. Rev. ed. Barcelona: Seix Barral, 2000.

—. "Resolutorio de cambios de Lázaro de Tormes (hacia 1552)." Problemas del Lazarillo. Madrid: Cátedra, I988. 93-ı12.

ROBLES, JUAN DE. "De la orden que en algunos pueblos de España se ha puesto en la limosna, para remedio de los verdaderos pobres." El gran debate sobre los pobres en el siglo XVI: Domingo de Soto y Juan de Robles, 1545. Ed. Félix Santolaria Sierra. Barcelona: Ariel, 2003. I15-97.

RODRíGUEZ, JUA N CARLos. La literatura del pobre. 2nd ed. Granada: Comares, $200 \mathrm{I}$. RONCERO LÓPEZ, VICTORIANO. De bufones y pícaros: La risa en la novela picaresca.

Madrid/Frankfurt: Iberoamericana/Vervuert, 20 Io. 
ROYO MARTÍNEZ, MARÍA DEL MAR. "La moneda castellana en la obra de El Lazarillo de Tormes." Cuadernos de Investigación Histórica 20 (2003): 219-38.

SÁn CH E Z, F RA nC IS C o J. An Early Bourgeois Literature in Golden Age Spain: Lazarillo de Tormes, Guzmán de Alfarache and Baltasar Gracián. Chapel Hill: North Carolina Studies in the Romance Languages and Literatures, 2003.

SARAVia de la CALle, luis. Instrucción de mercaderes. Madrid: Colección Joyas Bibliográficas 3, 1949.

SEMPERE Y GUARINOS, JUAN. Biblioteca española económico-política. Vol. I. Madrid: Sancha, I8OI.

s o b e Ja n o, g on Za lo. Forma literaria y sensibilidad social (Mateo Alemán, Galdós, Clarín, el 98 y Valle-Inclán). Madrid: Gredos, 1967.

soto, Domingo De. De la justicia y del derecho. Trans. Marcelino González Ordóñez. 5 vols. Madrid: Instituto de Estudios Políticos, 1967.

S PA D A C C I I , N I C H o L A s. "Estebanillo González and the Nature of Picaresque 'Lives."” Comparative Literature 30.3 (1978): 209-22.

т а в в в, м а т т. "The Great American Bubble Machine." Rolling Stone 5 Apr. 2010. N. pag. Web.

Vigo, A B E LA R D O DE L. Cambistas, mercaderes y banqueros en el Siglo de Oro español. Madrid: Biblioteca de Autores Cristianos, 1997.

VI L AR, J E A N. Literatura y economía: la figura satírica del arbitrista en el Siglo de Oro. Trans. Francisco Bustelo G. a del Real. Madrid: Revista de Occidente, I973. Villalón, CRistóbal De. Prouechoso tratado de ca[m]bios y co[n]tratacciones d[e] mercaderes, y reprouacion, de vsura. Valladolid: Francisco fernandez d[e] cordoua, I546. 